\title{
Grapes and their derivatives in modulation of cognitive decline: a critical review of epidemiological and randomized-controlled trials in humans
}

Patrizia Restania*, Ursula Fraderab, Jean-Claude Rufc, Creina Stockleyd, Pierre-Louis Teissedree, Simone Biellaa, Francesca Colomboa and Chiara Di Lorenzoa

${ }_{a}$ Dept. Pharmacological and Biomolecular Sciences. Università degli Studi di Milano, via Balzaretti 9, 20133 Milano, Italy; bDeutsche Weinakademie, Platz des Weines 2, 55294 Bodenheim, Germany; Wine Information Council, Brussels, Belgium; cScientific Coordinator at OIV - International Organisation of Vine and Wine, 18, rue d'Aguesseau, 75008 Paris, France; dSchool of Agriculture, Food and Wine, The University of Adelaide, South Australia, 5005 Australia; e Unité de recherche Enologie, Université de Bordeaux, EA 4577, USC 1366 INRA, ISVV, 33882 Villenave d'Ornon cedex, France; INRA, ISVV, USC 1366 Enologie, F-33140 Villenave d'Ornon, France.

Corresponding author: Patrizia Restani, Dept. of Pharmacological and Biomolecular Sciences, Via Balzaretti 9, 20133 Milano, Italy, Email: patrizia.restani@ unimi.it

Word count: 7.965 


\title{
Grapes and their derivatives in modulation of cognitive decline: a critical review of epidemiological and randomized-controlled trials in humans
}

\begin{abstract}
With an increase in life expectancy, the incidence of chronic degenerative pathologies such as dementia has progressively risen. Cognitive impairment leads to the gradual loss of skills, which results in substantial personal and financial cost at the individual and societal levels. Grapes and wines are rich in healthy compounds, which may help to maintain homeostasis and reduce the risk of several chronic illnesses, including dementia. This review analyzed papers that were systematically searched in PubMed, MEDLINE, Embase, and CAB-Abstract, using the association between grapes (or their derivatives) and their effects on cognitive functions in humans. Analysis was restricted to epidemiological and randomized-controlled studies. Consumption of grape juice (200-500 mL/day) and/or light-to-moderate wine (one to four glasses/day) was generally associated with improved cognitive performance, while the results for other alcoholic beverages were controversial and inconclusive. Bioactive molecules contained in grapes and wine were also considered, with particular attention paid to resveratrol. Due to the relatively high doses required (150-1000 mg/day) for bioactivity coupled with its low bioavailability, resveratrol is only one of the possible grapederived compounds that may partly underpin the beneficial effects of grapes on the central nervous system.
\end{abstract}

Keywords: cognitive functions, dementia, Alzheimer's disease, grapes, wine, resveratrol

\section{Introduction}

\section{Aging and cognition}

Aging is a well-known risk factor for cognitive decline, which is associated with an inability to maintain independence, physical activity, and social relationships (Murman 2015). An increase in life span is accompanied by both positive and negative effects. Although increased life expectancy enables prolonged relationships with family and friends, the gradual loss of cognitive function leads to problems for individuals, their 
relatives, and the societies in which they live. An increased life span is specifically associated with a higher incidence of chronic degenerative diseases, including dementias. The WHO (2015) reported 3.1 new cases of dementia in every 1000 inhabitants aged 6064 years old and 175 new cases in every 1000 inhabitants aged >95 years old for any given year. The incidence is higher in industrialized countries, but this is due at least partly to the difference in accessibility to medical districts and diagnostic criteria. Reduced physical activity, smoking, overweight/obesity, poor diet, and concomitant metabolic diseases can also increase the risk of dementia in developed countries, as reported by WHO (2015). The most common cause of dementia is Alzheimer's disease, which is particularly frequent in those older than 85 years old. Dementia from Alzheimer's disease is progressive, has variable prognosis, and differs from that due to normal decline from aging (Hugo and Ganguli 2014).

To address this "dementia pandemic", preventive strategies have been proposed by both national and international authorities (WHO 2013). Physical exercise and healthy dietary habits have been identified as some of the most efficient therapeutic approaches (Savica and Petersen 2011) and are recommended from early life.

\section{Diet, aging, and cognition}

Diet is a critical source of protective compounds, including both caloric (e.g., unsaturated fatty acids) and non-caloric (e.g., vitamins, minerals, phenolic compounds) nutrients. Diet contributes to maintaining homeostasis of the organism and reducing risk factors for several chronic and degenerative diseases.

Sofi et al. (2008) performed a meta-analysis on the impact of Mediterranean diet on health and considered 12 prospective studies including 1,574,299 subjects followed for a period ranging between 3 and 18 years. Adherence to the Mediterranean diet was directly associated with better health status as indicated by lower overall mortality (-9\%) 
and decreased prevalence of chronic degenerative diseases, such as cancers (-6\%) and Parkinson's/Alzheimer's diseases (-13\%). Although the term "Mediterranean diet" does not indicate a unique food pattern, this definition traditionally includes a high consumption of vegetables, legumes, fruits, and fish; the use of olive oil as the main source of lipids; and a moderate intake of red wine during meals (Visioli and Galli 2001; Mezzano et al. 2001; Giacosa et al. 2013).

Fruits and wine are important sources of phenolic compounds, which have been suggested to prevent the decay of senescence (for a review, see Gurău et al. 2018). The most important classes of phenolic compounds are:

- flavonoids such as flavones (apigenin), flavanols (catechins), condensed tannins (proanthocyanidins), and flavonols (quercetin, kaempferol, naringenin) and anthocyanins (red grapes)

- non-flavonoids such as stilbenes (resveratrol), lignans, phenolic acids, and hydrolysable tannins

- other classes of compounds such as ginsenosides, oleuropein, and spermidine

\section{Role of grapes and their derivatives as sources of healthy dietary compounds}

Despite geographical and religious differences, grapes and their derivatives (both nonfermented and fermented) are common dietary ingredients world-wide, especially in Mediterranean countries. Grapes are a rich source of bioactive compounds, including anthocyanins (red grapes), flavonols, catechins, procyanidins, organic acids, and stilbenes. The consumption of $100 \mathrm{~g}$ of fresh grapes contributes 3-6\% of the Recommended Daily Intake (RDI) of vitamins B1, B6, C, and E (FAO-OIV 2016), while phenolic compounds contribute to antioxidant and anti-inflammatory effects in cells and tissues of the body (Colombo et al. 2019). 
Although bioactive compounds in grapes differ quantitatively, most are conserved in the juice from grapes depending on the time and temperatures used in the production process, as these factors affect extraction efficiency and concentration of biocompounds. However, several biological effects of both grape and grape juice polyphenols have been observed (Colombo et al. 2019; Xia et al. 2010; Copetti et al. 2018).

Most bioactive properties of grapes are conserved in its juice as well as in raisins (dried grapes), previously described by Restani et al. (2016). Changes in bioactivity are observed in fermented derivatives of grapes, such as red, rosé, and white wines, as oenological processes and alcohol production can affect polyphenol extraction and lead to the production of new phenolic derivatives (e.g., tyrosol, flavanes, free phenolic acids, and hydrolyzable tannins) (Garrido and Borges 2013; Snopek et al, 2018). The higher polyphenol content in wines has been correlated to improvements in several biological parameters and metabolic functions including antioxidant activity and cardiovascular health) (Snopek et al. 2018). Beneficial effects on human health have been reported for all grape-based products (Guilford and Pezzuto 2011), although concerns have been raised for alcoholic beverages due to the adverse outcomes associated with their frequent abuse/misuse among adults and youths (WHO 2010).

To date, only few papers reported data on the effect of wine on cognitive function or diseases, but neither comprehensive review nor data on grape derivatives have been published.

The objective of this review was to perform a critical evaluation of data reported in the scientific literature, where grapes and their derivatives were considered in association with dementia, either as a protective or promoting agent.

\section{Materials and Methods}

Four of the most established scientific databases of references and abstracts in the life 
sciences (PubMed, MEDLINE, Embase, and CAB-Abstract) were systematically searched (from database inception to March 2019) using the terms "grape," "raisins," "wine," "Vitis vinifera," "resveratrol," "catechins," "anthocyanins," "quercetin," and "proanthocyanidins" in combination with "cognition," "brain," "dementia," "Alzheimer's disease," "CNS," "memory" "depression" "Parkinson," and "learning." Results were refined for "human studies" and "controlled trials."

The search by title and abstract resulted in the identification of 557 publications on both positive and negative associations between grapes/grape derivatives and cognition functions. Only human studies were included in the systematic review. To ensure the highest standard of scientific evidence, randomized, placebo-controlled (possibly double-blind) trials were selected. In the case of wine, most papers reported epidemiological studies; they were only included in this review if the study design was considered scientifically sound. After removing duplicates such as papers assessing alcohol and irrelevant papers, the final number of publications included in the review was 26.

\section{Results}

\section{Grapes as fresh fruit and juice}

Importance of fresh grapes, raisins, and juice in the diet

Grape production has demonstrated a progressive global increase from 65 million tons in 2000 to 73.3 million tons in 2017 (OIV 2018). In particular, table grape production increased from 15.7 million tons in 2000 to almost 27 million tons in 2014 . The main drivers of this market are the People's Republic of China and India (FAO-OIV 2016). A parallel increase in grape consumption has been observed worldwide from 15,111 to 26,208 million tons, corresponding to an increase of $73 \%$ from 2000 to 2014, with certain 
countries contributing more to this increase. The increase in table grape consumption in the same period exhibits notable differences in the five continents: $+59 \%$ in Africa, $+40 \%$ in America, $+112 \%$ in Asia, $+17 \%$ in Europe, and $+142 \%$ in Oceania (FAO-OIV 2016).

To better define the role of this fruit as a source of compounds with potential beneficial bioactivity, estimation of the average intake of each population was required. Considering the grape intake per capita and per year, the first 10 countries for the highest consumption (in kg/inhabitant) were: Albania (56.7), Turkmenistan (43.3), Macedonia (40.3), Armenia (32.3), Uzbekistan (31.7), Turkey (23.2), Tajikistan (19.1), Afghanistan (18.0), Egypt /16.1), and Greece (14.5) (FAO-OIV 2016).

Several bioactive properties of grapes are conserved in its juice, unless processed at extremely high temperatures (Copetti et al. 2018). The beneficial effects of grape juice in humans are supported by numerous studies. Khadem-Ansari et al. (2011) reported an association between the consumption of red grape juice and an increase in high-density lipoprotein (HDL) cholesterol and reduction in homocysteine, which are both implicated in the modulation of cardiovascular diseases in healthy people. Moreover, a significant increase in plasma antioxidant capacity was reported in humans after concomitant consumption of grapes and apple juice (Yuan et al. 2011). The present state of the grape juice market and consumption is not easily evaluated due to the different technological processes applied (concentration, dilution, etc.) as well as their multiple destinations (inclusion in mixed juices, sweetener, etc.) (FAO-OIV 2016).

With regard to raisins, the method of drying grapes may differentially affect the phenolic content. The sun drying process (2-3 weeks long) generally reduces phenolic acids and flavonols by $90 \%$ and $60 \%$, respectively, due to enzymatic oxidation. Alternatively, raisins can be briefly exposed to hot water and subsequently dehydrated for 20-24 hours. In some cases, grapes can be treated with $\mathrm{SO}_{2}$ before the drying process 
to reduce polyphenol oxidase activation and preserve polyphenols. Raisins produced by both methods have demonstrated positive biological effects (Di Lorenzo et al. 2016; Williamson and Carughi 2010), but till now no correlation has been reported with cognitive function.

\section{Grape juice, and cognitive function}

Studies performed in humans to investigate the effects of grape juice consumption on cognitive decline are listed in Table 1; for each trial, the experimental design, main characteristics, and results are summarized. The papers selected in this review present homogeneous results demonstrating positive effects of grape juices in modulating the early stages of cognitive decline (mild cognitive decline). All studies listed in Table 1 reported an improvement of cognitive functions in the active versus control group after both single dose (Haskell-Ramsay et al. 2017) and long-term (up to 6 months) supplementation (Cañete da Costa et al. 2017; Krikorian et al. 2012, 2010; Lamport et al. 2016; Lee, Torosyan, and Silverman 2017). The most encouraging results were obtained in tests that measured reaction times, verbal skills, degree of orientation, learning, and memory.

A positron emission tomography (PET) study by Lee et al. (2017) demonstrated that subjects in the control group developed significant decline in metabolic activity of the right posterior cingulate cortex and left superior posterolateral temporal cortex, areas significantly affected in the early stages of Alzheimer's disease. These results suggest that grapes and their fresh derivatives may have a protective role against cognitive decline in humans. 


\section{Wine}

\section{Wine production and consumption}

From 2000 to 2017, the global production of wine exhibited a fluctuating trend with a maximum of $298 \mathrm{mhL}$ in 2004 and a minimum of $250 \mathrm{mhL}$ as an estimate of the 2017 production. In the same period, global wine consumption demonstrated a stable trend close to $240 \mathrm{mhL}$, ranging from 228 in 2001 to 250 in 2017/2018 (OIV 2018). Italy, France, and Spain are the three most important producers of wine in the world, followed by USA, Argentina, China, Australia, Germany, and South Africa. In 2017, the largest consumers were Portugal (58.8 L per capita), France (50.7 L per capita), and Italy (44.0 L per capita) (OIV 2018).

\section{Wine and cognitive function}

The correlation between positive or negative effects of wine and cognition has been considered in different papers. A paper by Stockley indicated that light to moderate wine consumption was neuroprotective, although heavy or abusive alcohol consumption was neurotoxic ( Stockley 2016). Several papers have examined the association between alcoholic beverage consumption and depression with conflicting results (Gea et al. 2012, 2013; Wang and Patten 2001). As the association between depression and dementia is far from conclusive (for a review, see Muliyala and Varghese 2010), depression will not be considered in this review. The most significant papers considering wine consumption and dementia are summarized in Table 2. For ethical reasons, clinical trials with alcoholic beverages cannot be performed. As such, the selected studies were conducted using epidemiological approaches. All studies supported positive effects of light to moderate wine consumption on dementia, although crucial details were often lacking; for example, some studies did not discriminate between the consumption of white and red wines or 
their alcoholic content.

Generally speaking, light to moderate wine consumption seems to be associated with an improvement in cognitive performance (Arntzen et al. 2010; Leibovici et al. 1999) and a reduced risk of developing any dementia (Lindsay et al. 2002; Luchsinger et al. 2004; Mehlig et al. 2008; Mukamal et al. 2003; Orgogozo et al. 1997; Ruitenberg et al. 2002; Truelsen, Thudium, and Grønbæk 2002). The effects of wine were typically greater than those obtained with an equivalent quantity of alcohol from other alcoholic beverages, such as beer or spirits (Arntzen et al. 2010; Gu et al. 2014; Lindsay et al. 2002; Luchsinger et al. 2004; Mehlig et al. 2008; Mukamal et al. 2003; Truelsen, Thudium, and Grønbæk 2002).

\section{Alcohol and other active molecules in wine}

\section{Alcohol and cognitive functions}

Studies have reported that alcohol consumption was associated with effects on cognitive function; a subset of these studies distinguished the type of beverage used, whereas others did not. In the studies assessing the effects on cognition according to type of beverage (wine, beer, or spirits) (Panza et al., 2009), wine was generally more effective than other alcoholic beverages for improving cognitive performance.

A review of papers considering alcohol consumption per se by Panza et al. (2009) indicated that the current evidence for protective effects of light to moderate consumption of alcohol on cognitive decline (including dementia) was suggestive only. Indeed, several papers considering alcohol per se (mainly defined as number of drinks) showed positive cognitive effects in abstainers compared to those in light to moderate drinkers (Espeland et al. 2005; Ganguli et al. 2005; Zuccalà et al. 2001; Rehm et al. 2019), but the quality of the studies did not always permit definitive conclusions to be drawn or to identify a dose 
of alcohol that could be considered neuro-protective without associated negative effects. Moreover, in such "unspecified" approaches, bias may be more probable in terms of effects of habits (alcohol with or without a meal), lifestyle, or other factors that could contribute to the improvement or deterioration of cognitive functions.

\section{Phenolic compounds and cognitive functions}

Since the first report on the "French paradox," wine has been studied widely. Particular interest has been paid to the role of phenolic compounds in providing beneficial health effects, with special emphasis on resveratrol. Wine-derived resveratrol has been frequently associated with a reduced risk of cardiovascular diseases, in a J-shaped relationship. However, the data obtained from in vitro studies are being reconsidered, as a consequence of the low bioavailability of resveratrol (Stockley et al. 2012). Data from studies assessing the efficacy of phenolic compounds on cognitive performance are listed in Table 3. Most studies on resveratrol have reported positive effects on cognitive function, but the doses used (150-1000 mg/day) are far from the usual intake associated with food and wine consumption. The content of resveratrol in grapes and wines has been reported by different authors; according to a review by Weiskirchen and Weiskirchen (2016), these levels are: $92-1604$ and $59-1759 \mu \mathrm{g} / \mathrm{kg}$ fresh weight for red and white grapes, respectively, and 0.36-1.97, 0-1.09, and $0.29 \mathrm{mg} / \mathrm{L}$ for red, white, and rosé wines, respectively. As such, the lowest active level of resveratrol $(150 \mathrm{mg} /$ day $)$ reported by Evans et al. $(2016,2017)$ would be reached with an intake of approximately $85 \mathrm{~kg} /$ day of grapes or at least $76 \mathrm{~L} /$ day of red wine and more than $130 \mathrm{~L} /$ day of white or rosé wines.

\section{Discussion}

The studies examined in this review suggest the following: 
- Consumption of 200-500 mL/day of grape juice is correlated with positive effects on cognitive performance;

- Light to moderate wine consumption (one to four glasses/day, in which the effective volume was not always defined) is associated with improved cognitive performance in older individuals compared to that in abstainers with a lower risk of dementia, especially Alzheimer's disease;

- Some studies indicate that beneficial effects on cognitive performance are independent of the type of alcoholic beverage consumed, which is in contrast to most studies where better performance was associated with wine consumption; and

- When searching for bioactive molecules involved in the protective effects of wine on cognitive performance, most authors performed studies with polyphenolic compounds, especially resveratrol. The studies included in this review suggest that, given the high doses required and low bioavailability of resveratrol, this compound should be considered as only one of the possible effectors of beneficial outcomes on the central nervous system.

It is important to highlight that wine contains a complex mixture of molecules, the total activity of which can be represented by the sum of the activity of single compounds, synergistic, or antagonistic effects. Studies performed in vivo or in vitro with purified molecules have limited biological significance, and their extrapolation to human in vivo settings may lead to erroneous conclusions.

Finally, it should be kept in mind that the number of papers identified was limited. It is therefore essential to consider the observations reported in this review critically and be aware that further observational studies are necessary for confirmation of bioactivity. 


\section{Acknowledgments}

This research did not receive any specific grant from funding agencies in the public, commercial, or not-for-profit sectors. Most authors are government delegates and/or experts to the International Organization of Vine and Wine's (OIV) Commission IV Safety and Health. Although this work was initiated under the auspices of the OIV and its Consumption, Nutrition and Health expert group, the statements herein are the sole responsibility of the undersigned authors.

Authors from Università degli Studi di Milano prepared this paper in the framework of MIUR Progetto Eccellenza (without any specific budget).

Declaration of Interest Statement

Authors have no conflict of interests to declare.

\section{References}

Anton, Stephen D., Natalie Ebner, Joseph M. Dzierzewski, Zvinka Z. Zlatar, Matthew J. Gurka, Vonetta M. Dotson, Joshua Kirton, Robert T. Mankowski, Michael Marsiske, and Todd M. Manini. 2018. "Effects of 90 Days of Resveratrol Supplementation on Cognitive Function in Elders: A Pilot Study." The Journal of Alternative and Complementary Medicine 24 (7): 725-732. doi:10.1089/acm.2017.0398.

Arntzen, K. A., H. Schirmer, T. Wilsgaard, and E. B. Mathiesen. 2010. "Moderate Wine Consumption Is Associated with Better Cognitive Test Results: A 7 Year Follow up of 5033 Subjects in the Tromsø Study.” Acta Neurologica Scandinavica 122 (SUPPL. 190): 23-29. doi:10.1111/j.1600-0404.2010.01371.x.

Cañete da Costa, Pedro, Gilson Pires Dorneles, Ivy Reichert Vital da Silva, Cintia Laura Pereira de Araujo, Gustavo Pereira Reinaldo, Alessandra Peres, Cláudia Funchal, Pedro Dal Lago, Caroline Dani, and Viviane Rostirola Elsner. 2017. “Chronic Purple 
Grape Juice Consumption Induces Age-Dependent Changes on Cognitive Function in Elderly Women.” Journal of Systems and Integrative Neuroscience 3 (1): 1-6. doi:10.15761/JSIN.1000149.

Colombo, Francesca, Chiara Di Lorenzo, Luca Regazzoni, Marco Fumagalli, Enrico Sangiovanni, Luís Peres de Sousa, Luigi Bavaresco, et al. 2019. "Phenolic Profiles and Anti-Inflammatory Activities of Sixteen Table Grape ( Vitis Vinifera L.) Varieties." Food \& Function 10 (4). Royal Society of Chemistry: 1797-1807. doi:10.1039/c8fo02175a.

Copetti, Cristiane, Fernanda Wouters Franco, Eduarda Da Rosa Machado, Marcela Bromberger Soquetta, Andréia Quatrin, Vitor De Miranda Ramos, José Cláudio Fonseca Moreira, Tatiana Emanuelli, Cláudia Kaehler Sautter, and Neidi Garcia Penna. 2018. “Acute Consumption of Bordo Grape Juice and Wine Improves Serum Antioxidant Status in Healthy Individuals and Inhibits Reactive Oxygen Species Production in Human Neuron-Like Cells.” Journal of Nutrition and Metabolism 2018: 11. doi:10.1155/2018/4384012.

Di Lorenzo, Chiara, Enrico Sangiovanni, Marco Fumagalli, Elisa Colombo, Gianfranco Frigerio, Francesca Colombo, Luis Peres de Sousa, Ahmet Altindisli, Patrizia Restani, and Mario Dell ' Agli. 2016. "Evaluation of the Anti-Inflammatory Activity of Raisins (Vitis Vinifera L.) in Human Gastric Epithelial Cells: A Comparative Study." International Journal of Molecular Sciences 17 (7): e1156. doi:10.3390/ijms 17071156.

Espeland, Mark A., Lin Gu, Kamal H. Masaki, Robert D. Langer, Laura H. Coker, Marcia L. Stefanick, Judith Ockene, and Stephen R. Rapp. 2005. "Association between Reported Alcohol Intake and Cognition: Results from the Women's Health Initiative Memory Study." American Journal of Epidemiology 161 (3): 228-238. 
doi:10.1093/aje/kwi043.

Evans, Hamish M., Peter R.C. Howe, and Rachel H.X. Wong. 2016. "Clinical Evaluation

of Effects of Chronic Resveratrol Supplementation on Cerebrovascular Function, Cognition, Mood, Physical Function and General Well-Being in Postmenopausal Women-Rationale and Study Design.” Nutrients $8 \quad$ (3): 150. doi:10.3390/nu8030150.

Evans, Hamish M., Peter R.C. Howe, and Rachel H.X. Wong. 2017. "Effects of Resveratrol on Cognitive Performance, Mood and Cerebrovascular Function in PostMenopausal Women; a 14-Week Randomised Placebo-Controlled Intervention Trial." Nutrients 9 (1): 27. doi:10.3390/nu9010027.

FAO-OIV. 2016. "Table and Dried Grapes. Non-Alcoholic Products of the Vitivinicultural Sector Intended for Human Consumption." In FAO-OIV Focus 2016, 62. FAO/OIV. http://www.fao.org/3/a-i7042e.pdf.

Ganguli, Mary, J. Vander Bilt, J. A. Saxton, C. Shen, and H. H. Dodge. 2005. “Alcohol Consumption and Cognitive Function in Late Life: A Longitudinal Community Study." Neurology 65 (8): 1210-1217. doi:10.1212/01.wnl.0000180520.35181.24.

Garrido, Jorge, and Fernanda Borges. 2013. "Wine and Grape Polyphenols - A Chemical Perspective." Food Research International 54: 1844-1858. doi:10.1016/j.foodres.2013.08.002.

Gea, Alfredo, Juan J. Beunza, Ramón Estruch, Almudena Sánchez-Villegas, Jordi SalasSalvadó, Pilar Buil-Cosiales, Enrique Gómez-Gracia, et al. 2013. “Alcohol Intake, Wine Consumption and the Development of Depression: The PREDIMED Study.” BMC Medicine 11 (1). doi:10.1186/1741-7015-11-192.

Gea, Alfredo, Miguel A. Martinez-Gonzalez, Estefania Toledo, Almudena SanchezVillegas, Maira Bes-Rastrollo, Jorge M. Nuñez-Cordoba, Carmen Sayon-Orea, and 
Juan J. Beunza. 2012. “A Longitudinal Assessment of Alcohol Intake and Incident Depression: The SUN Project.” BMC Public Health 12 (1): 954. doi:10.1186/14712458-12-954.

Giacosa, Attilio, Roberto Barale, Luigi Bavaresco, Piers Gatenby, Vincenzo Gerbi, Jaak Janssens, Belinda Johnston, et al. 2013. "Cancer Prevention in Europe: The Mediterranean Diet as a Protective Choice." European Journal of Cancer Prevention 22 (1): 90-95. doi:10.1097/CEJ.0b013e328354d2d7.

Gu, Yian, Nikolaos Scarmeas, Erica Eaton Short, José A. Luchsinger, Charles DeCarli, Yaakov Stern, Jennifer J. Manly, Nicole Schupf, Richard Mayeux, and Adam M. Brickman. 2014. "Alcohol Intake and Brain Structure in a Multiethnic Elderly Cohort.” Clinical Nutrition $33 \quad$ (4): $\quad$ 662-667. doi:10.1016/j.clnu.2013.08.004.Alcohol.

Guilford, Jacquelyn M., and John M. Pezzuto. 2011. "Wine and Health: A Review." American Journal of Enology and Viticulture 62 (4): 471-486. doi:10.5344/ajev.2011.11013.

Gurău, Felicia, Simone Baldoni, Francesco Prattichizzo, Emma Espinosa, Francesco Amenta, Antonio Domenico Procopio, Maria Cristina Albertini, Massimiliano Bonafè, and Fabiola Olivieri. 2018. “Anti-Senescence Compounds: A Potential Nutraceutical Approach to Healthy Aging." Ageing Research Reviews 46: 14-31. doi:10.1016/j.arr.2018.05.001.

Haskell-Ramsay, C. F., R. C. Stuart, E. J. Okello, and A. W. Watson. 2017. "Erratum to: Cognitive and Mood Improvements Following Acute Supplementation with Purple Grape Juice in Healthy Young Adults (European Journal of Nutrition, (2017), 56, 8, (2621-2631), 10.1007/S00394-017-1454-7).” European Journal of Nutrition 56 (8). Springer Berlin Heidelberg: 2633. doi:10.1007/s00394-017-1541-9. 
Hugo, Julie, and Mary Ganguli. 2014. "Dementia and Cognitive Impairment. Epidemiology, Diagnosis, and Treatment." Clinics in Geriatric Medicine 30: 421442. doi:10.1016/j.cger.2014.04.001.

Kennedy, David O., Emma L. Wightman, Jonathon L. Reay, Georg Lietz, Edward J. Okello, Anthea Wilde, and Crystal F. Haskell. 2010. "Effects of Resveratrol on Cerebral Blood Flow Variables and Cognitive Performance in Humans: A DoubleBlind, Placebo-Controlled, Crossover Investigation." American Journal of Clinical Nutrition 91 (6): 1590-1597. doi:10.3945/ajcn.2009.28641.

Kesse-Guyot, Emmanuelle, Léopold Fezeu, Valentina A. Andreeva, Mathilde Touvier, Augustin Scalbert, Serge Hercberg, and Pilar Galan. 2011. "Total and Specific Polyphenol Intakes in Midlife Are Associated with Cognitive Function Measured 13 Years Later.” The Journal of Nutrition 142 (1): 76-83. doi:10.3945/jn.111.144428. Khadem-Ansari, Mohammad H, Yousef Rasmi, and Fatemeh Ramezani. 2011. "Effects of Red Grape Juice Consumption on High Density Lipoprotein-Cholesterol, Apolipoprotein AI, Apolipoprotein B and Homocysteine in Healthy Human Volunteers." The Open Biochemistry Journal 4: 96-99. doi:10.2174/1874091x01004010096.

Köbe, Theresa, A. Veronica Witte, Ariane Schnelle, Valentina A. Tesky, Johannes Pantel, Jan Philipp Schuchardt, Andreas Hahn, Jens Bohlken, Ulrike Grittner, and Agnes Flöel. 2017. "Impact of Resveratrol on Glucose Control, Hippocampal Structure and Connectivity, and Memory Performance in Patients with Mild Cognitive Impairment.” Frontiers in Neuroscience 11: 105. doi:10.3389/fnins.2017.00105.

Krikorian, Robert, Erin L. Boespflug, David E. Fleck, Amanda L. Stein, Jolynne D. Wightman, Marcelle D. Shidler, and Sara Sadat-Hossieny. 2012. "Concord Grape Juice Supplementation and Neurocognitive Function in Human Aging." Journal of 
Agricultural and Food Chemistry 60 (23): 5736-5742. doi:10.1021/jf300277g.

Krikorian, Robert, Tiffany A. Nash, Marcelle D. Shidler, Barbara Shukitt-Hale, and James A. Joseph. 2010. “Concord Grape Juice Supplementation Improves Memory Function in Older Adults with Mild Cognitive Impairment.” British Journal of Nutrition 103 (5): 730-734. doi:10.1017/S0007114509992364.

Lamport, Daniel J., Clare L. Lawton, Natasha Merat, Hamish Jamson, Kyriaki Myrissa, Denise Hofman, Helen K. Chadwick, Frits Quadt, Jolynne D. Wightman, and Louise Dye. 2016. "Concord Grape Juice, Cognitive Function, and Driving Performance: A 12-Wk, Placebo-Controlled, Randomized Crossover Trial in Mothers of Preteen Children." American Journal of Clinical Nutrition 103 (3): 775-783. doi:10.3945/ajen.115.114553.

Lee, Jooyeon, Nare Torosyan, and Daniel H. Silverman. 2017. "Examining the Impact of Grape Consumption on Brain Metabolism and Cognitive Function in Patients with Mild Decline in Cognition: A Double-Blinded Placebo Controlled Pilot Study.” Experimental Gerontology 87. Elsevier Inc.: 121-128. doi:10.1016/j.exger.2016.10.004.

Leibovici, Didier, Karen Ritchie, Bernard Ledésert, and Jacques Touchon. 1999. "The Effects of Wine and Tobacco Consumption on Cognitive Performance in the Elderly: A Longitudinal Study of Relative Risk." International Journal of Epidemiology 28 (1): 77-81. doi:10.1093/ije/28.1.77.

Lindsay, Joan, Danielle Laurin, René Verreault, Réjean Hébert, Barbara Helliwell, Gerry B. Hill, and Ian McDowell. 2002. "Risk Factors for Alzheimer's Disease: A Prospective Analysis from the Canadian Study of Health and Aging." American Journal of Epidemiology 156 (5): 445-453. doi:10.1093/aje/kwf074.

Luchsinger, Jose A., Ming Xin Tang, Maliha Siddiqui, Steven Shea, and Richard 
Mayeux. 2004. "Alcohol Intake and Risk of Dementia." Journal of the American Geriatrics Society 52 (4): 540-546. doi:10.1111/j.1532-5415.2004.52159.x.

Mehlig, K., I. Skoog, X. Guo, M. Schütze, D. Gustafson, M. Waern, S. Östling, C. Björkelund, and L. Lissner. 2008. “Alcoholic Beverages and Incidence of Dementia: 34-Year Follow-up of the Prospective Population Study of Women in Göteborg." American Journal of Epidemiology 167 (6): 684-691. doi:10.1093/aje/kwm366.

Mezzano, D., F. Leighton, C. Martínez, G. Marshall, A. Cuevas, O. Castillo, O. Panes, et al. 2001. "Complementary Effects of Mediterranean Diet and Moderate Red Wine Intake on Haemostatic Cardiovascular Risk Factors.” European Journal of Clinical Nutrition 55 (6): 444-451. doi:10.1038/sj.ejcn.1601202.

Moussa, Charbel, Michaeline Hebron, Xu Huang, Jaeil Ahn, Robert A. Rissman, Paul S. Aisen, and R. Scott Turner. 2017. "Resveratrol Regulates Neuro-Inflammation and Induces Adaptive Immunity in Alzheimer's Disease." Journal of Neuroinflammation 14 (1). Journal of Neuroinflammation: 1-10. doi:10.1186/s12974-016-0779-0.

Mukamal, Kenneth J., Lewis H. Kuller, Annette L. Fitzpatrick, W. T. Longstreth, Murray A. Mittleman, and David S. Siscovick. 2003. "Prospective Study of Alcohol Consumption and Risk of Dementia in Older Adults." Journal of the American Medical Association 289 (11): 1405-1413. doi:10.1001/jama.289.11.1405.

Muliyala, Krishna, and Mathew Varghese. 2010. "The Complex Relationship between Depression and Dementia.” Annals of Indian Academy of Neurology 13 (6): 69-73. Murman, Daniel L. 2015. "The Impact of Age on Cognition." Seminars in Hearing 36 (3): 111-121. doi:10.1055/s-0035-1555115.

OIV. 2018. "OIV Statistical Report on World Vitiviniculture." International Organisation of Vine and Wine, 27. doi:64/19/6835 [pii] 1 10.1158/0008- 
5472.CAN-04-1678.

Orgogozo, J M, J F Dartigues, S Lafont, L Letenneur, D Commenges, R Salamon, S Renaud, and M B Breteler. 1997. "Wine Consumption and Dementia in the Elderly: A Prospective Community Study in the Bordeaux Area." Revue Neurologique 153 (3): 185-192. doi:10.1016/S0301-0104(01)00489-X.

Panza, Francesco, Cristiano Capurso, Alessia D’Introno, Anna M. Colacicco, Vincenza Frisardi, Maria Lorusso, Andrea Santamato, et al. 2009. “Alcohol Drinking, Cognitive Functions in Older Age, Predementia, and Dementia Syndromes." Journal of Alzheimer's Disease 17 (1): 7-31. doi:10.3233/JAD-2009-1009.

Rehm, Jürgen, Omer S. M. Hasan, Sandra E. Black, Kevin D. Shield, and Michaël Schwarzinger. 2019. “Alcohol Use and Dementia: A Systematic Scoping Review.” Alzheimer's Research \& Therapy 11 (1). doi:10.1186/s13195-018-0453-0.

Restani, Patrizia, Gianfranco Frigerio, Francesca Colombo, Luis Peres de Sousa, Ahmet Altindişli, Raul Francisco Pastor, and Chiara Di Lorenzo. 2016. "Raisins in Human Health: A Review." BIO Web of Conferences 7: 04005. doi:10.1051/bioconf/20160704005.

Ruitenberg, Annemieke, John C. Van Swieten, Jacqueline C.M. Witteman, Kala M. Mehta, Cornelia M. Van Duijn, Albert Hofman, and Monique M.B. Breteler. 2002. "Alcohol Consumption and Risk of Peripheral Arterial Disease - The Rotterdam Study." Lancet 359: 281-86. doi:10.1093/aje/155.4.332.

Savica, R., and R. C. Petersen. 2011. "Prevention of Dementia." Psychiatric Clinics of North America 34 (1): 127-145.

Snopek, Lukas, Jiri Mlcek, Lenka Sochorova, Mojmir Baron, Irena Hlavacova, Tunde Jurikova, Rene Kizek, Eva Sedlackova, and Jiri Sochor. 2018. “Contribution of Red Wine Consumption to Human Health Protection." Molecules 23 (7): 1-16. 
doi:10.3390/molecules23071684.

Sofi, Francesco, Francesca Cesari, Rosanna Abbate, Gian Franco Gensini, and Alessandro Casini. 2008. "Adherence to Mediterranean Diet and Health Status: Meta-Analysis.” Bmj 337 (7671): 673-675. doi:10.1136/bmj.a1344.

Stampfer, Meir J., Jae Hee Kang, Jennifer Chen, Rebecca Cherry, and Francine Grodstein. 2005. "Effects of Moderate Alcohol Consumption on Cognitive Function in Women." New England Journal of Medicine 352 (3): 245-253. doi:10.1056/nejmoa041152.

Stockley, Creina S. 2016. "Wine Consumption, Cognitive Function and Dementias - A Relationship?" Nutrition and Aging 3 (2-4): 125-137. doi:10.3233/nua-150055. Stockley, Creina, Pierre Louis Teissedre, Mladen Boban, Chiara Di Lorenzo, and Patrizia Restani. 2012. "Bioavailability of Wine-Derived Phenolic Compounds in Humans: A Review." Food and Function 3 (10): 995-1007. doi:10.1039/c2fo10208k.

Truelsen, Thomas, Dorte Thudium, and Morten Grønbæk. 2002. “Amount and Type of Alcohol and Risk of Dementia The Copenhagen City Heart Study." Neurology 59: $1313-1319$.

Visioli, Francesco, and Claudio Galli. 2001. "The Role of Antioxidants in the Mediterranean Diet.” Lipids 36 (S1): S49-S52. doi:10.1007/s11745-001-0682-z.

Wang, Jianli, and Scott B. Patten. 2001. "Alcohol Consumption and Major Depression: Findings from a Follow-up Study." Canadian Journal of Psychiatry 46: 632-638. doi:10.1177/070674370104600708.

Weiskirchen, Sabine, and Ralf Weiskirchen. 2016. "Resveratrol: How Much Wine Do You Have to Drink to Stay Healthy?" Advances in Nutrition: An International Review Journal 7 (4): 706-718. doi:10.3945/an.115.011627.

WHO. 2010. "Global Strategy to Reduce the Harmful Use of Alcohol." World Health 
Organization. http://www.who.int/substance_abuse/alcstratenglishfinal.pdf.

WHO. 2013. “Mental Health Action Plan 2013 - 2020.” World Health Organization. https://www.who.int/mental_health/action_plan_2013/en/.

WHO. 2015. "The Epidemiology and Impact of Dementia - Current State and Future Trends." World Health Organization. https://www.who.int/mental_health/neurology/dementia/dementia_thematicbrief_e pidemiology.pdf.

Wightman, Emma L, Crystal F Haskell-Ramsay, Jonathon L Reay, Gary Williamson, Tristan Dew, Wei Zhang, and David O Kennedy. 2015. "The Effects of Chronic Trans-Resveratrol Supplementation on Aspects of Cognitive Function, Mood, Sleep, Health and Cerebral Blood Flow in Healthy, Young Humans.” The British Journal $\begin{array}{lll}\text { of } & \text { Nutrition } & 114\end{array}$ doi:http://dx.doi.org/10.1017/S0007114515003037.

Williamson, Gary, and Arianna Carughi. 2010. "Polyphenol Content and Health Benefits of Raisins." Nutrition Research 30 (8). Elsevier Inc.: 511-519. doi:10.1016/j.nutres.2010.07.005.

Witte, A. V., L. Kerti, D. S. Margulies, and A. Floel. 2014. "Effects of Resveratrol on Memory Performance, Hippocampal Functional Connectivity, and Glucose Metabolism in Healthy Older Adults.” Journal of Neuroscience 34 (23): 7862-7870. doi:10.1523/JNEUROSCI.0385-14.2014.

Xia, En Qin, Gui Fang Deng, Ya Jun Guo, and Hua Bin Li. 2010. "Biological Activities of Polyphenols from Grapes.” International Journal of Molecular Sciences 11 (2): 622-646. doi:10.3390/ijms11020622.

Yuan, Linhong, Liping Meng, Weiwei Ma, Zhongxin Xiao, Xian Zhu, Jin Fang Feng, 
Huanling Yu, and Rong Xiao. 2011. "Impact of Apple and Grape Juice Consumption on the Antioxidant Status in Healthy Subjects." International Journal of Food Sciences and Nutrition 62 (8): 844-850. doi:10.3109/09637486.2011.587399.

Zuccalà, Giuseppe, Graziano Onder, Claudio Pedone, Matteo Cesari, Francesco Landi, Roberto Bernabei, and Alberto Cocchi. 2001. "Dose-Related Impact of Alcohol Consumption on Cognitive Function in Advanced Age: Results of a Multicenter Survey." Alcoholism: Clinical and Experimental Research 25 (12): 1743-1748. doi:10.1111/j.1530-0277.2001.tb02185.x. 
Table 1. Studies performed in humans in which grape juice consumption was correlated with cognitive function/dementia

\begin{tabular}{|c|c|c|c|c|}
\hline $\begin{array}{l}\text { Cohort and } \\
\text { study details }\end{array}$ & Tested product & Objective of the study & Main outcomes & Ref. \\
\hline $\begin{array}{l}35 \text { healthy women } \\
\text { (age } 69.5 \pm 7.0 \mathrm{y} ; 19>70 \text { years) } \\
\text { Trial comparing performance } \\
\text { before and after intervention }\end{array}$ & $\begin{array}{l}400 \mathrm{~mL} / \text { day of purple grape juice } \\
\text { for } 30 \text { days. } \\
\text { Juice was characterized for total } \\
\text { phenol, catechin, and naringin } \\
\text { levels }\end{array}$ & $\begin{array}{l}\text { To verify the effect of chronic consumption of } \\
\text { grape juice on cognitive functions }\end{array}$ & $\begin{array}{l}\text { At Mini Mental State Examination (MMSE), } \\
\text { cognitive performances were higher after } \\
\text { supplementation with purple juice. The effect } \\
\text { was more evident in > 70-year-old women. }\end{array}$ & $\begin{array}{l}\text { (Cañete da Costa } \\
\text { et al. 2017) }\end{array}$ \\
\hline $\begin{array}{l}20 \text { healthy adults } \\
(7 \mathrm{M}, 13 \mathrm{~F} ; 21.1 \pm 0.89 \mathrm{y}) \\
\text { Randomized, double-blind } \\
\text { placebo-controlled, crossover } \\
\text { study }\end{array}$ & $\begin{array}{l}\text { Active group: purple grape juice } \\
\text { ( } 200 \mathrm{~mL} \text { ) plus } 30 \mathrm{~mL} \text { of Schweppes } \\
\text { black- currant flavor cordial. } \\
\text { Placebo group: } 200 \mathrm{~mL} \text { white grape } \\
\text { juice plus } 10 \mathrm{~mL} \text { blackcurrant } \\
\text { flavor cordial and } 20 \mathrm{~mL} \text { cold } \\
\text { water. } \\
\text { Single serving }\end{array}$ & $\begin{array}{l}\text { To study the effect of purple grape juice or } \\
\text { sugar-matched control on cognitive functions } \\
\text { and mood assessed by Computerised Mental } \\
\text { Performance Assessment System }\end{array}$ & $\begin{array}{l}\text { Purple grape juice acutely enhanced aspects of } \\
\text { cognition and mood. No significant effects of } \\
\text { juice were observed in memory measures. } \\
\text { Potential mechanisms to be confirmed: } \\
\text { Modulation of cerebral blood flow, gluco- } \\
\text { regulation, and inhibition of monoamino } \\
\text { oxidase activity. }\end{array}$ & $\begin{array}{l}\text { (Haskell-Ramsay } \\
\text { et al. 2017) }\end{array}$ \\
\hline $\begin{array}{l}12 \text { subjects with mild cognitive } \\
\text { decline (MCD) without } \\
\text { dementia } \\
\text { (8 M, } 4 \text { F; } 78.2 \pm 5.0 \text { y) } \\
\text { Three times/day for } 12 \text { weeks } \\
\text { Randomized, double-blind, } \\
\text { placebo-controlled study }\end{array}$ & $\begin{array}{l}\text { Active group: Concord grape juice } \\
\text { (Vitis labrusca) at the daily dose of } \\
\text { 6-9 mL/kg bodyweight (bw) } \\
\text { Placebo group: similar beverage } \\
\text { without polyphenols } \\
\text { Three times/day for } 12 \text { weeks }\end{array}$ & $\begin{array}{l}\text { To assess the role of Concord grape juice in } \\
\text { modulating cognitive functions by treatment } \\
\text { (before and after) or placebo: } \\
\text { 1. California Verbal Learning Test (verbal } \\
\text { learning and retention); } \\
\text { 2. Spatial Paired Associate Learning Test } \\
\text { (Non-verbal memory); } \\
\text { 3. Geriatric Depression Scale (mood) }\end{array}$ & $\begin{array}{l}\text { A significant effect on verbal learning }(\mathrm{p}=0.04) \\
\text { by Concord grape juice versus placebo was } \\
\text { observed, indicating a possible enhancement of } \\
\text { cognitive function in older adults with early } \\
\text { memory decline. No appreciable effect on } \\
\text { depressive symptoms. }\end{array}$ & $\begin{array}{l}\text { (Krikorian et al. } \\
2010 \text { ) }\end{array}$ \\
\hline $\begin{array}{l}21 \text { subjects with MCD } \\
(11 \mathrm{M}, 10 \mathrm{~F} ; 68-90 \mathrm{y}) \\
\text { Randomized, double-blind } \\
\text { placebo-controlled study }\end{array}$ & $\begin{array}{l}\text { Active group: Concord grape juice } \\
\text { (Vitis labrusca) at the daily dose of } \\
\text { 6-9 } \mathrm{mL} / \mathrm{kg} \mathrm{bw} \\
\text { Placebo group: similar beverage } \\
\text { without polyphenols } \\
16 \text { weeks }\end{array}$ & $\begin{array}{l}\text { To assess the role of Concord grape juice in } \\
\text { modulating neurocognitive functions by } \\
\text { performing before and after treatment or } \\
\text { placebo: } \\
\text { - California Verbal Learning Test-II (memory } \\
\text { function) } \\
\text { - Functional magnetic resonance imaging } \\
\text { (fMRI) (brain activation during working } \\
\text { memory tests) }\end{array}$ & $\begin{array}{l}\text { A significant enhancement in neurocognitive } \\
\text { functions, reduced semantic interference on } \\
\text { memory tasks, and greater activation in anterior } \\
\text { and posterior regions of the right hemisphere } \\
\text { were observed in Concord grape juice group } \\
\text { versus placebo }\end{array}$ & $\begin{array}{l}\text { (Krikorian et al. } \\
\text { 2012) }\end{array}$ \\
\hline
\end{tabular}


Table 1. Studies performed in humans in which grape juice consumption was correlated with cognitive function/dementia (continued)

\begin{tabular}{|c|c|c|c|c|}
\hline $\begin{array}{l}\text { Cohort and } \\
\text { study details }\end{array}$ & Tested product & Objective of the study & Main outcomes & Ref. \\
\hline $\begin{array}{l}16 \text { healthy mothers }(40-50 \\
\text { years-old) of preteen children } \\
(<13 \text { y), working for } 30 \mathrm{~h} / \text { week } \\
\text { (stressful lifestyle) } \\
\text { Randomized, placebo- } \\
\text { controlled, crossover study }\end{array}$ & $\begin{array}{l}\text { Active group: } 355 \mathrm{~mL} / \text { day of } \\
\text { Concord grape juice (Vitis } \\
\text { labrusca) containing } 777 \mathrm{mg} \text { total } \\
\text { polyphenols } \\
\text { Placebo group: Energy drink } \\
\text { similar for taste and appearance } \\
12 \text { weeks }\end{array}$ & $\begin{array}{l}\text { To study the role of Concord grape juice in } \\
\text { modulating neurocognitive functions by } \\
\text { performing at } 6 \text { and } 12 \text { months: } \\
\text { - Visual spatial learning test of immediate and } \\
\text { delayed recall (verbal memory); } \\
\text { - Visual spatial learning test of immediate and } \\
\text { delayed recall (nonverbal spatial memory); } \\
\text { - Rapid visual information processing } \\
\text { (executive function); } \\
\text { - Grooved Pegboard (psychomotor skill); } \\
\text { - Tower of Hanoi (executive function); } \\
\text { - Driving performance }\end{array}$ & $\begin{array}{l}\text { Significant improvements in immediate spatial } \\
\text { memory and driving performance in active } \\
\text { versus placebo group were noted. } \\
\text { There was evidence of an enduring effect in } \\
\text { the active group when moved to the placebo } \\
\text { arm (cross-over). }\end{array}$ & $\begin{array}{l}\text { (Lamport et al. } \\
\text { 2016) }\end{array}$ \\
\hline $\begin{array}{l}10 \text { subjects with MCD } \\
(5 \mathrm{M}, 5 \mathrm{~F} ; 72.2 \pm 4.7 \mathrm{y}) \\
\text { Randomized, double-blind } \\
\text { placebo-controlled study }\end{array}$ & $\begin{array}{l}\text { Active group: } 36 \mathrm{~g} \text { of freeze-dried } \\
\text { grape powder (from fresh red, } \\
\text { green, and blue-black California } \\
\text { grapes) in } 237 \mathrm{~mL} \text { of water } \\
\text { Placebo group: polyphenol-free } \\
\text { beverage } \\
\text { Twice daily ( } 72 \mathrm{~g} / \text { day) for } 6 \\
\text { months }\end{array}$ & $\begin{array}{l}\text { To study the effects of grapes on cognitive } \\
\text { functions by performing at start and } 6 \text { months: } \\
\text { - A battery of neuropsychological tests ( } 24 \\
\text { tests); } \\
\text { - Standardized Volume of Interest (sVOI) and } \\
\text { statistical parametric mapping methods were } \\
\text { applied to Positron Emission Tomography } \\
\text { (PET) scans to identify significant regional } \\
\text { cerebral metabolic changes. }\end{array}$ & $\begin{array}{l}\text { - Placebo versus active group: significant } \\
\text { metabolic decline in sVOI of the right } \\
\text { posterior cingulate cortex }(\mathrm{p}=0.01) \text { and left } \\
\text { superior temporal cortex ( } \mathrm{p}=0.04) \\
\text { - Placebo group: significant decline in left } \\
\text { prefrontal, cingulate, and left superior } \\
\text { posterolateral temporal cortex }(\mathrm{p}<0.01) \text {; } \\
\text { - Active group: stable brain metabolism; } \\
\text { - Placebo-group: decline in brain regions } \\
\text { generally affected in the early stages of } \\
\text { Alzheimer's disease; } \\
\text { - Active group: no decline observed. }\end{array}$ & $\begin{array}{l}\text { (Lee, Torosyan, } \\
\text { and Silverman } \\
\text { 2017) }\end{array}$ \\
\hline
\end{tabular}


Table 2. Studies performed in humans in which wine consumption was correlated with cognitive function/dementia

\begin{tabular}{|c|c|c|c|c|}
\hline $\begin{array}{l}\text { Cohort and } \\
\text { study details }\end{array}$ & Beverages included & Objective of the study & Main outcomes & Ref. \\
\hline $\begin{array}{l}5,033 \text { stroke-free people } \\
(2,227 \mathrm{M} ; 2,806 \mathrm{~F} ; \\
\text { age } 25-85 \mathrm{y}) \\
\text { Longitudinal population- } \\
\text { based study }\end{array}$ & $\begin{array}{l}\text { Consumption of wine, beer, or spirits for } \\
14 \text { days: } \\
\text { None } \\
<1 \text { glass } \\
3-4 \text { glasses } \\
\geq 5 \text { glasses }\end{array}$ & $\begin{array}{l}\text { Impact of consumption of different } \\
\text { alcoholic beverages on cognitive } \\
\text { function after } 7 \text { years of follow-up. } \\
\text { Tests performed: verbal memory test, } \\
\text { digit-symbol coding test, and tapping } \\
\text { test }\end{array}$ & $\begin{array}{l}\text { Moderate wine consumption was independently associated } \\
\text { with improved performance on all cognitive tests in both } \\
\text { men and women. No significant improvement was observed } \\
\text { with beer or spirits. }\end{array}$ & $\begin{array}{l}\text { (Arntzen et } \\
\text { al. 2010) }\end{array}$ \\
\hline $\begin{array}{l}589 \text { multi-ethnic } \\
\text { community residents in } \\
\text { New York. } \\
(130 \mathrm{M} \text {; 265 F; } \\
\text { Age > 60 years; } \\
\text { mean age 80.1 } 15.5 \mathrm{y}) \\
\text { Cross-sectional study }\end{array}$ & $\begin{array}{l}\text { Consumption of wine, beer, or liquor over } \\
\text { the prior year: } \\
\text { - None }(\mathrm{n}=409) \\
\text { - Light to moderate: } 0-30 \text { drinks/month } \\
\text { for females; } 0-60 \text { drinks/month for } \\
\text { males }(\mathrm{n}=180) \\
\text { - Heavy: }>30 \text { drinks/month for females: } \\
>60 \text { drinks/month for males) ( } \mathrm{n}=14) \\
1 \text { drink }=10 \mathrm{~g} \text { alcohol equiv. } 113 \mathrm{~g} \text { wine }\end{array}$ & $\begin{array}{l}\text { To evaluate the association between } \\
\text { alcoholic beverages and brain } \\
\text { structure measured by magnetic } \\
\text { resonance imaging (MRI) }\end{array}$ & $\begin{array}{l}\text { Compared to non-drinking, light-to-moderate total alcohol } \\
(\mathrm{b}=0.007, \mathrm{p}=0.04) \text { or wine }(\mathrm{b}=0.008, \mathrm{p}=0.05) \text { intake, but } \\
\text { not beer or liquor intake, was associated with larger total } \\
\text { brain volume (TBV). Further analysis showed a dose- } \\
\text { response association between alcohol ( } \mathrm{p} \text {-trend }=0.03 \text { ) or } \\
\text { wine ( } \mathrm{p} \text {-trend }=0.006 \text { ) and TBV. Overall, alcohol intake was } \\
\text { not associated with white matter hyperintensity volume } \\
\text { (WMHV) or brain infarcts. }\end{array}$ & $\begin{array}{l}\text { (Gu et al., } \\
2014)\end{array}$ \\
\hline $\begin{array}{l}259 \text { subjects } \\
\text { (age: >60 y) with } \\
\text { deterioration in cognitive } \\
\text { functions } \\
\text { Longitudinal study } \\
\text { Population-based study }\end{array}$ & $\begin{array}{l}3-4 \text { glasses/day } \times 3 \text { years } \\
\text { No detail on types of wine consumed }\end{array}$ & $\begin{array}{l}\text { To assess the relationship between } \\
\text { wine and tobacco consumption and } \\
\text { cognitive changes using an extensive } \\
\text { battery of cognitive tests: attention, } \\
\text { primary memory, secondary memory, } \\
\text { implicit memory, visuospatial ability, } \\
\text { and language }\end{array}$ & $\begin{array}{l}\text { Moderate wine consumption ( } 3-4 \text { glasses per day) was } \\
\text { associated with a fourfold reduction in the risk of } \\
\text { Alzheimer's disease }(\mathrm{OR}=0.26) \text { in non-institutionalized } \\
\text { subjects. Wine consumption was associated with an } \\
\text { increased risk of decline over time in attention }(\mathrm{p}=0.06) \text { and } \\
\text { secondary memory }(\mathrm{p}=0.09) \text {. No clear combined effect of } \\
\text { smoking and drinking was observed, although smoking } \\
\text { increased the risk of decline in language performance when } \\
\text { adjusted for wine consumption. }\end{array}$ & $\begin{array}{l}\text { (Leibovici } \\
\text { et al. 1999) }\end{array}$ \\
\hline $\begin{array}{l}4,615 \text { subjects without } \\
\text { dementia at baseline } \\
(>65 \mathrm{y}) \\
\text { Longitudinal population- } \\
\text { based study }\end{array}$ & $\begin{array}{l}\text { Questionnaire reporting risk factors for } \\
\text { Alzheimer's disease, including wine } \\
\text { consumption }\end{array}$ & $\begin{array}{l}\text { Role of risk factors on the induction } \\
\text { of Alzheimer's disease (AD) }\end{array}$ & $\begin{array}{l}\text { At } 5 \text { years after enrolment: } 194 \text { AD cases, } 3,894 \text { subjects } \\
\text { cognitively normal. } \\
\text { Increasing age, low education, and napolipoprotein E e } 4 \\
\text { allele were significantly associated with increased risk of } \\
\text { AD. Use of non-steroidal anti-inflammatory drugs, } \\
\text { alcoholic drink consumption, coffee consumption, and } \\
\text { physical activity were associated with a reduced risk of AD. } \\
\text { Odds ratio were } 0.68 \text { for all alcoholic drinks; } 0.49 \text { for wine; } \\
0.78 \text { for spirits; and } 0.84 \text { for beer. }\end{array}$ & $\begin{array}{l}\text { (Lindsay et } \\
\text { al. 2002) }\end{array}$ \\
\hline
\end{tabular}


Table 2. Studies performed in humans in which wine consumption was correlated to cognitive function/dementia (continued)

\begin{tabular}{|c|c|c|c|c|}
\hline $\begin{array}{l}\text { Cohort and } \\
\text { study details }\end{array}$ & Beverages included & Objective of the study & Main outcomes & Ref. \\
\hline $\begin{array}{l}980 \text { community subjects } \\
\text { without dementia at } \\
\text { baseline with and without } \\
\text { APO- } \varepsilon 4 \text { allele } \\
\text { (age } \geq 65 \text { y) } \\
\text { Prospective study }\end{array}$ & $\begin{array}{l}\text { Weekly consumption of wine, beer, } \\
\text { liquor: } \\
\text { - } 1-3 \text { serving/month } \\
\text { - } 1 \text { serving/week } \\
\text { - } 1-2 \text { serving/week } \\
\text { - } 5-6 \text { serving/week } \\
\text { - } 1 \text { serving/day } \\
\text { - } 2-3 \text { serving/day } \\
\text { - } 4-5 \text { serving/day } \\
\text { - } 6 \text { serving/day } \\
\text { (1 serving of wine }=11 \mathrm{~g} \text { alcohol })\end{array}$ & $\begin{array}{l}\text { Prospective relationship for } 4 \text { years of } \\
\text { alcoholic beverage consumption and } \\
\text { risk of AD disease and dementia } \\
\text { associated with stroke }\end{array}$ & $\begin{array}{l}\text { Light to moderate intake }(0.1-36 \mathrm{~g} \text { alcohol/day, up to three } \\
\text { servings/day) of wine was associated with a lower risk of } \\
\mathrm{AD} \text { in elderly people without APO- } \varepsilon 4 \text { allele. } \\
\text { Intake of liquor, beer, and total alcohol was not associated } \\
\text { with lower risk of AD. }\end{array}$ & $\begin{array}{l}\text { (Luchsinger } \\
\text { et al. 2004) }\end{array}$ \\
\hline $\begin{array}{l}1,462 \text { women } \\
\text { (age } 38-60 \text { y) } \\
\text { Prospective study }\end{array}$ & $\begin{array}{l}\text { Frequency of alcohol consumption: } \\
\text { - Never } \\
\text { - Not in the last } 10 \text { years } \\
\text { - Not in the last year } \\
\text { - Monthly } \\
\text { - Weekly } \\
\text { - Several times/week } \\
\text { - Daily }\end{array}$ & $\begin{array}{l}\text { To evaluate the association between } \\
\text { different types of alcoholic beverages } \\
\text { and 34-year incidence of dementia. }\end{array}$ & $\begin{array}{l}\text { Wine was protective for dementia }(\mathrm{OR}=0.6) \text { and the } \\
\text { association was strongest when wine was the only beverage } \\
\text { consumed }(\mathrm{OR}=0.3) \text {. The protective effect of wine was } \\
\text { stronger in smokers. Consumption of spirits at baseline was } \\
\text { associated with an increase in dementia }(\mathrm{OR}=1.5) \text {. }\end{array}$ & $\begin{array}{l}\text { (Mehlig et } \\
\text { al. 2008) }\end{array}$ \\
\hline $\begin{array}{l}373 \text { subjects with incident } \\
\text { dementia (age } 77.8 \pm 5.5 \text { y) } \\
\text { and } 373 \text { controls (age } \\
77.5 \pm 5.2 \text { y) } \\
\text { Prospective study }\end{array}$ & $\begin{array}{l}\text { Weekly consumption of wine, beer, or } \\
\text { spirits: } \\
\text { - }<1 \text { drink, } \\
\text { - } 1 \text { to } 6 \text { drinks, } \\
\text { - }>7 \text { drinks }\end{array}$ & $\begin{array}{l}\text { Prospective relationship for } 6 \text { years } \\
\text { of alcoholic beverage consumption } \\
\text { and risk of dementia. }\end{array}$ & $\begin{array}{l}\text { The lowest odd ratios of dementia were in old adults who } \\
\text { consumed: }>7 \text { drinks/weekly of wine }(0.62) ; 1 \text { to } 6 \text { of beer } \\
(0.74) ;<1 \text { of liquor }(0.84) \text {. } \\
\text { A higher consumption of beer and spirit increased the } \\
\text { odds ratio. }\end{array}$ & $\begin{array}{l}\text { (Mukamal } \\
\text { et al. 2003) }\end{array}$ \\
\hline $\begin{array}{l}2,273 \text { community residents } \\
\text { without dementia at } \\
\text { baseline } \\
\text { (age } \geq 65 \text { y) } \\
\text { Prospective study }\end{array}$ & $\begin{array}{l}\text { Wine consumption: } \\
\text { - None (<1 drink/week) } \\
\text { - Mild ( } 2 \text { drinks/week to } 2 \text { drinks/day } \\
\text { - } \text { Moderate (3-4 drinks/day) } \\
\text { - Heavy ( } \geq 5 \text { drinks/day) }\end{array}$ & $\begin{array}{l}\text { Prospective relationship for } 3 \text { years of } \\
\text { wine consumption and risk of } \\
\text { dementia. }\end{array}$ & $\begin{array}{l}\text { The lowest risk of incident dementia was observed in } \\
\text { moderate wine consumers }(\mathrm{OR}=0.19, \mathrm{p}<0.01) \text { and that of } \\
\text { Alzheimer's disease }(\mathrm{OR}=0.28, \mathrm{p}<0.05)\end{array}$ & $\begin{array}{l}\text { (Orgogozo } \\
\text { et al. 1997) }\end{array}$ \\
\hline
\end{tabular}


Table 2. Studies performed in humans in which wine consumption was correlated to cognitive function/dementia (continued)

\begin{tabular}{|c|c|c|c|c|}
\hline $\begin{array}{l}\text { Cohort and } \\
\text { study details }\end{array}$ & Beverages included & Objective of the study & Main outcomes & Ref. \\
\hline $\begin{array}{l}5,395 \text { subjects }(\text { age } \geq 55 \text { y) } \\
\text { without dementia at } \\
\text { baseline } \\
\text { Prospective study } \\
6 \text { years }\end{array}$ & $\begin{array}{l}\text { Consumption of wine, beer, liquor, or } \\
\text { fortified wine: } \\
\text { - None } \\
\text { - }<1 \text { drink/week } \\
\text { - } 1 \text { to } 7 \text { drinks/week } \\
\text { - } 1 \text { to } 3 \text { drinks/day } \\
\text { - }>4 \text { drinks/day }\end{array}$ & $\begin{array}{l}\text { Association between alcohol } \\
\text { consumption and risk of dementia. }\end{array}$ & $\begin{array}{l}\text { Light-to-moderate drinking (one to three drinks per day) } \\
\text { was significantly associated with a lower risk of any } \\
\text { dementia (hazard ratio } 0 \cdot 58 \text { ), Alzheimer's disease }(0.72 \text { ), } \\
\text { and vascular dementia (hazard ratio } 0 \cdot 30 \text { ). No evidence of } \\
\text { different dementia risk in relation to the alcoholic beverage } \\
\text { consumed. }\end{array}$ & $\begin{array}{l}\text { (Ruitenberg } \\
\text { et al. 2002) }\end{array}$ \\
\hline $\begin{array}{l}11,102 \text { women from the } \\
\text { Nurses' Health Study } \\
\text { (age } 70-81 \text { y) } \\
\text { Prospective study } \\
2 \text { years }\end{array}$ & Alcohol intake (as wine, beer, or liquor) & $\begin{array}{l}\text { To assess cognitive scores with the } \\
\text { level of alcohol consumption ( }<5 \text { up } \\
\text { to } 30 \mathrm{~g} / \text { day) }\end{array}$ & $\begin{array}{l}\text { Moderate drinkers }(<15 \mathrm{~g} / \text { day of alcohol }) \text { demonstrated } \\
\text { better cognitive scores than that of non-drinkers and a } \\
\text { reduced risk of decline in performance over a } 2 \text {-year period } \\
(\mathrm{RR}=0.85) \text {. No statistically significant difference was } \\
\text { observed between data due to the different type of alcoholic } \\
\text { beverages. }\end{array}$ & $\begin{array}{l}\text { (Stampfer et } \\
\text { al. 2005) }\end{array}$ \\
\hline $\begin{array}{l}83 \text { subjects with dementia } \\
\text { and } 1,626 \text { nondemented } \\
\text { controls (age } \geq 65 \mathrm{y} \text { ) } \\
\text { Case-control nested in a } \\
\text { cohort study }\end{array}$ & $\begin{array}{l}\text { Intake of alcohol, type of alcoholic } \\
\text { beverage in the previous } 15 \text { years }\end{array}$ & $\begin{array}{l}\text { Effect of alcohol and wine on risk of } \\
\text { dementia }\end{array}$ & $\begin{array}{l}\text { Average weekly total alcohol intake had no significant } \\
\text { effect on risk of dementia. Monthly and weekly intake of } \\
\text { wine was significantly associated with a lower risk of } \\
\text { dementia. For beer and spirits, only a monthly intake of beer } \\
\text { was associated with an increased risk. Odds ratio for wine } \\
\text { were: monthly intake } 0.56 \text {; weekly intake } 0.36 \text {; daily intake } \\
0.49 \text {. }\end{array}$ & $\begin{array}{l}\text { (Truelsen, } \\
\text { Thudium, } \\
\text { and } \\
\text { Grønbæk } \\
\text { 2002) }\end{array}$ \\
\hline
\end{tabular}


Table 3. Studies performed in humans in which the intake of active compounds from wine was correlated to cognitive function/dementia

\begin{tabular}{|c|c|c|c|c|}
\hline $\begin{array}{l}\text { Cohort and } \\
\text { study details }\end{array}$ & Tested product & Objective of the study & Main outcomes & Ref. \\
\hline $\begin{array}{l}\text { 2,574 participants } \\
\text { (mean age at evaluation=66 y) } \\
\text { Cohort study }\end{array}$ & $\begin{array}{l}\text { Total polyphenol intake: } \\
\text { - Males: } 1.28 \pm 0.51 \\
\text { - Females: } 1.12 \pm 0.48\end{array}$ & $\begin{array}{l}\text { To assess the role of polyphenol } \\
\text { supplementation in improving } \\
\text { cognitive functions tested by } \\
\text { phonemic semantic fluency, the RI- } 48 \\
\text { Cued Recall test, the Trail Making } \\
\text { test, and Forward and Backward Digit } \\
\text { Span. }\end{array}$ & $\begin{array}{l}\text { High intake of specific polyphenols, including flavonoids } \\
\text { and phenolic acids, could play a role in maintaining verbal } \\
\text { memory, which is frequently impaired in pathological brain } \\
\text { aging. }\end{array}$ & $\begin{array}{l}\text { (Kesse- } \\
\text { Guyot et al. } \\
2011)\end{array}$ \\
\hline $\begin{array}{l}32 \text { healthy, community-dwelling, } \\
\text { overweight old adult } \\
\text { (age } 79 \pm 14 \text { y, } 65-93 \text { y) } \\
\text { Double-blind, Phase IIa } \\
\text { randomized, placebo-controlled } \\
\text { trial }\end{array}$ & $\begin{array}{l}\text { Three groups: } \\
\text { - Placebo } \\
\text { - } 300 \mathrm{mg} / \text { day resveratrol } \\
\text { - } 1000 \mathrm{mg} / \text { day resveratrol }\end{array}$ & $\begin{array}{l}\text { To study the effect of } 90 \text { days of } \\
\text { chronic treatment with resveratrol on } \\
\text { cognitive function } \\
\text { Cognitive functions were assessed } \\
\text { with a battery of tests }\end{array}$ & $\begin{array}{l}\text { Supplementation with resveratrol at a dose of } 1000 \mathrm{mg} / \mathrm{day} \\
\text { selectively improved psychomotor speed when compared } \\
\text { to supplementation with placebo or } 300 \mathrm{mg} / \mathrm{day} \text { of } \\
\text { resveratrol. No further significant effects on other cognitive } \\
\text { domains in older adults were observed. }\end{array}$ & $\begin{array}{l}\text { (Anton et al. } \\
\text { 2018) }\end{array}$ \\
\hline $\begin{array}{l}80 \text { post-menopausal women } \\
\text { (age: } 61.5 \pm 1.1 \text { y; } 45-85 \mathrm{y}) \\
\text { Randomized placebo-controlled } \\
\text { intervention trial }\end{array}$ & $\begin{array}{l}\text { Placebo or two capsules/day of } \\
\text { resveratrol }(2 \times 75 \mathrm{mg}) \text { for } 14 \\
\text { weeks }\end{array}$ & $\begin{array}{l}\text { Effect of chronic supplementation } \\
\text { with resveratrol on cerebrovascular } \\
\text { function, cognition, and mood in post- } \\
\text { menopausal women. }\end{array}$ & $\begin{array}{l}\text { Resveratrol improved cerebrovascular responsiveness } \\
(17 \%) \text { to both hypercapnic }(\mathrm{p}=0.010) \text { and cognitive stimuli } \\
(\mathrm{p}=0.002) \text {. Significant improvements in performance of } \\
\text { cognitive tasks related to verbal memory }(\mathrm{p}=0.041) \text { and } \\
\text { overall cognitive performance }(\mathrm{p}=0.020) \text { were observed. A } \\
\text { trend for improvement in mood was observed but this did } \\
\text { not reach statistical significance. }\end{array}$ & $\begin{array}{l}\text { (Evans, } \\
\text { Howe, and } \\
\text { Wong 2017; } \\
\text { Evans, } \\
\text { Howe, and } \\
\text { Wong 2016) }\end{array}$ \\
\hline $\begin{array}{l}22 \text { healthy adults (age } 24.8 \text { y; } 21-29 \\
\text { y) } \\
\text { Randomized, placebo-controlled, } \\
\text { double-blind, crossover study }\end{array}$ & $\begin{array}{l}\text { Placebo or } 2 \text { doses of resveratrol } \\
(250 \text { and } 500 \mathrm{mg}) \text { on separate } \\
\text { days }\end{array}$ & $\begin{array}{l}\text { To assess the effect of resveratrol on } \\
\text { cognitive performance and localized } \\
\text { cerebral blood flow variables. }\end{array}$ & $\begin{array}{l}\text { Resveratrol dose-dependently increased cerebral blood } \\
\text { flow measured during task performance. Cognitive } \\
\text { functions were not affected. }\end{array}$ & $\begin{array}{l}\text { (Kennedy et } \\
\text { al. 2010) }\end{array}$ \\
\hline $\begin{array}{l}40 \text { participants with mild cognitive } \\
\text { impairment }(21 \mathrm{~F} \text {; age } 50-80 \mathrm{y}) \\
\begin{array}{l}\text { Randomized, } \\
\text { interventional study }\end{array}\end{array}$ & $\begin{array}{l}\text { Placebo or resveratrol } \\
\text { mg/day) for } 26 \text { weeks }\end{array}$ & $\begin{array}{l}\text { To evaluate the effect of resveratrol } \\
\text { on neuropsychological testing for } \\
\text { assessing learning and memory. }\end{array}$ & No significant differences in memory performance. & $\begin{array}{l}\text { (Köbe et al. } \\
2017 \text { ) }\end{array}$ \\
\hline $\begin{array}{l}119 \text { patients with mild-moderate } \\
\text { Alzheimer's disease } \\
\text { Randomized, placebo-controlled, } \\
\text { double-blind, multi-site study }\end{array}$ & $\begin{array}{l}\text { Placebo or resveratrol } 500 \mathrm{mg} \\
\text { orally once daily (with a dose } \\
\text { escalation by } 500-\mathrm{mg} \text { increments } \\
\text { every } 13 \text { weeks, ending with } \\
1,000 \mathrm{mg} \text { twice daily). }\end{array}$ & $\begin{array}{l}\text { To evaluate if resveratrol regulated } \\
\text { neuro-inflammation and induced } \\
\text { adaptive immunity in AD. }\end{array}$ & $\begin{array}{l}\text { Markers of neurodegenerative disease and } \\
\text { metalloproteinase (MMP) in cerebrospinal fluid (CSF) and } \\
\text { plasma were measured. } \\
\text { At } 52 \text { weeks, resveratrol-treated group showed several } \\
\text { changes in CSF and plasma biomarkers, indicating that }\end{array}$ & $\begin{array}{l}\text { (Moussa et } \\
\text { al. 2017) }\end{array}$ \\
\hline
\end{tabular}


52 weeks

60 healthy subjects

$(51 \mathrm{~F} ;$ age $18-29 \mathrm{y})$

Randomized, placebo-controlled, double-blind, parallel-groups study

46 healthy adults (18 F; age: $50-80$ y; BMI: $25-30 \mathrm{~kg} / \mathrm{m} 2)$

Randomized intervention/control

study resveratrol modulated neuroinflammation and induced adaptive immunity.

Placebo or resveratrol $500 \mathrm{mg}$ To assess the role of resveratrol The only cognitive improvement at day 28 was a beneficial with $10 \mathrm{mg}$ piperine for 28

supplementation on performance of

(Wightman

supplemc

col the 3-back tand al 2015)

subtractions, rapid visual information

processing, and 3-back)

Placebo or $200 \mathrm{mg} /$ day resveratrol for 26 weeks

To assess if supplementation with resveratrol would enhance memory performances

Before and after placebo/RES, subjects underwent memory tasks and neuroimaging. Participants receiving RES showed a significant improvement in retention of words over $30 \mathrm{~min}(\mathrm{p}=0.038)$ that correlated with increased hippocampal functional connectivity.
Witte et al.

2014) 